\title{
Review
}

\section{Type 2 (non-insulin-dependent) diabetes mellitus New genetics for old nightmares}

\author{
S. O'Rahilly', J.S. Wainscoat ${ }^{2}$ and R.C. Turner ${ }^{1}$ \\ ' Diabetes Research Laboratories, Radcliffe Infirmary, and 2 Department of Haematology, John Radcliffe Hospital, Oxford, UK
}

Summary. In the last five years, genetic markers for a large number of diseases have been localised using linkage analysis of DNA polymorphisms in affected families. The site of the genetic defect or defects leading to Type 2 (non-insulindependent) diabetes mellitus, a common illness with a major genetic component, remains unknown. This is due, at least in part, to the lack of large well-defined Type 2 diabetic pedigrees suitable for linkage analysis. There are several features of the disease which make large pedigrees difficult to find. The late age of onset of most probands means that informative older generations are often dead, while there is difficulty in detecting disease in younger generations. The diagnostic criteria for diabetes are, as yet, dependent on an arbitrary cut-off along a continuum of plasma glucose. The high prev- alence of the disease may also produce problems as, in any given family, diabetogenic genes may be contributed by more than one parent. Varieties of the disease with a well-defined inheritance, such as maturity onset diabetes of youth, are more suitable for linkage analysis but might be due to defects at a different gene locus. Despite these difficulties, once large well-defined pedigrees have been found, linkage analysis using both candidate genes and random highly polymorphic markers is the strategy most likely to find genetic markers for the disease.

Key words: Genetics, Type 2 (non-insulin-dependent) diabetes, linkage analysis, restriction fragment length polymorphism.
Type 2 (non-insulin-dependent) diabetes mellitus is known to have a strong genetic basis and is among the commonmost metabolic disorders both in developed and developing countries [1]. It has enormous public health consequences with a two- or three-fold increase in cardiovascular mortality rates and a large cost in terms of morbidity and disability [1]. Despite considerable research into the aetiology of Type 2 diabetes, the nature of its inheritance remains unknown.

J.V. Neel, the American geneticist, first referred to diabetes as a "geneticist's nightmare" [2]. He pointed out that the phenotype is probably heterogenous, has an unknown basis and is not clearly defined; it has a variable age of onset and is influenced in its manifestations by environmental factors. In the 1970's a major cause of heterogeneity was clarified with the distinction between Type 1 (insulin-dependent) diabetes, with its immunological basis and major histocompatibility complex associations, and the more common non-insulin dependent or Type 2 diabetes [3, 4]. Indeed, this has led to the characterisation of a major susceptibility gene for Type 1 diabetes [5]. In 1980 David Comings perceived the dawn of a new era in human genetics which was to be brought about by recombinant DNA technology, and commented, "Since the degree of departure from our previous approaches and the potential of this procedure are so great, one will not be guilty of hyperbole in calling it the New Genetics" [6]. The rate at which genetic diseases have been mapped and characterised in the subsequent decade have justified this dramatic appelation. In spite of these advances Type 2 diabetes has not yet divulged its genetic secrets to investigators. Some of the reasons for the slow progress will be discussed, in order to indicate how previously encountered difficulties might be overcome. This may also be relevant to other common disorders with a major genetic component, such as the hyperlipidaemias.

\section{Lessons from other diseases}

Recombinant DNA technology has led to a revolution in medical genetics, including the chromosomal localisation of several genetic diseases for which no biochemical defect is known. Using restriction enzymes and radioactively-labelled DNA probes, differing lengths of non-coding DNA sequences or single base- 
pair changes at restriction enzyme cutting sites are identified as DNA restriction fragment length polymorphisms (RFLPs) [7]. These have rendered most of the genome amenable to investigation [8]. The main successes in the definition of disease markers have used the techniques of linkage analysis of RFLPs in pedigrees as the initial strategy. Initially, diseases with a clear mode of inheritance and presentation in childhood such as cystic fibrosis [9] and Duchenne muscular dystrophy [10], were successfully localised. Using the same techniques, markers for diseases with some age-dependent penetrance, such as adult polycystic kidney disease [11], multiple endocrine neoplasia [12], polyposis coli [13] and the neurofibromatoses [14] have also been found. Even conditions which have been thought to have a complex multifactorial basis, such as Manic-Depression [15] and Alzheimer's disease [16] have proved amenable to investigation; genetic markers have been reported for both diseases. Given the proven track record of linkage analysis in large pedigrees as an initial step in the genetic localisation of inherited disorders it would appear that the potential application of these techniques to Type 2 diabetes should be examined critically.

\section{Population studies of Type 2 diabetes and their limitations}

A large number of studies have examined the allelic frequencies of particular genetic markers in Type 2 diabetic versus non-diabetic populations in an attempt to find a marker that may be in linkage disequilibrium with a disease-causing gene. Significant positive associations with Type 2 diabetes have been reported for various HLA antigens in African Blacks [17], Pima Indians [18] and Finns [19]; with the Rhesus blood group and Haptoglobin polymorphism in Mexican Americans [20] and with the 5'-flanking region of the insulin gene in Danish Caucasians [21] and in a racially mixed United States population [22].

Emery has clearly pointed out the limitations of this form of study [23], including the high risk of obtaining a spuriously positive result, particularly if the control group is not matched closely for ethnic background. Positive disease associations with genetic markers in a population are often interpreted as implying linkage disequilibrium between the marker and a nearby "disease" gene. Linkage disequilibrium implies that a disease-causing mutation originally occurred in one individual or in a small population of subjects who had a specific allele at a nearby genetic "marker" locus. These two loci were physically so close that throughout the generations of descendants of the original affected subject/subjects, they have not been separated during meoitic recombination, despite the many opportunities for this to occur. A single recombination event in an affected individual is amplified in his des- cendants and linkage disequilibrium may be lost in the contemporary population. For these reasons, linkage disequilibrium exists only across very short chromosomal distances, of the order of 100 kilobases $(\mathrm{kb})$ [24]. Indeed if a mutation had occurred far in the evolutionary past, with many subsequent opportunities for recombination, it may not even be possible to demonstrate linkage disequilibrium over much shorter distances.

Thus, association studies relying on linkage disequilibrium in a population are not powerful ways of searching for genetic markers linked to a disease, although they can be useful once a candidate gene has been identified.

\section{Linkage analysis}

Linkage analysis is a statistical technique that has been used in classical genetics since 1911 [25]. Two genetic loci that are physically close on the same chromosome are unlikely to be separated during the meiotic division which occurs during the formation of gametes. The likelihood of separation increases, non-linearly, with chromosomal distance. By studying the inheritance of genetic markers in pedigrees, linkage analysis allows estimation of the genetic distance between two such markers on the basis of the number of recombination events that have occurred between them. Within a family the changes that a crossover at meiosis will separate adjacent genes is much less likely than in a population. Thus, family studies can detect linkage up to a distance of about $15,000 \mathrm{~kb}$ compared to the $100 \mathrm{~kb}$ for linkage disequilibrium in a population [24]. This makes it feasible to study random, highly polymorphic markers which are not necessarily very close to the disease locus rather than restricting studies to candidate genes, which may have limited polymorphism.

One can estimate the number of informative meioses (and therefore pedigree size) required to find linkage. Given a marker which recombines with the disease at a rate of $10 \%$ then, on average, 19 meoises will be required to prove linkage and approximately 9 to reject it unequivocally [24]. This underlines the need for large, well-defined families.

\section{Family studies of Type 2 diabetes}

Linkage analysis in diabetic families has been attempted particularly in the specific type of diabetes referred to as maturity-onset diabetes of the young (MODY) in which there is clearly defined dominant inheritance of a mild form of the disease which presents in the second or third decade [26]. Candidate genes such as the insulin [27] and insulin receptor genes [28] have been examined and there has been no convincing linkage in any family although a role for a rare insulin receptor 
allele in some families has been proposed [28]. As yet, there have been no reports of systematic linkage studies of MODY using random highly polymorphic DNA RFLPs such as has been undertaken in other diseases, although studies of the more traditional protein and erythrocyte enzyme polymorphisms in MODY pedigrees have to date been unsuccessful [29].

MODY families, with definite dominant inheritance over 3 generations, are rare; but will continue to be useful in future linkage analysis studies. As the phenotpye in this condition differs from "common" Type 2 diabetes in age of onset and natural history there is a probability that the genetic defects in these conditions may be unrelated.

\section{Definition of the mode of inheritance of Type 2 diabetes}

It is essential to define the mode of inheritance of a disease in the families under investigation before attempting to study its genetic linkage. The identical twin studies of Barnett, Pyke et al. showing a near 100\% concordance in non-insulin-dependent diabetic pairs [30], point to a major genetic determinant, but tell us nothing about whether the inherited defects are monogenic or polygenic. In three populations where diabetes is common, a bimodality of glucose tolerance has been demonstrated, which strongly suggests a major single gene influence on the development of diabetes [31-33].

The problem of defining the inheritance of Type 2 diabetes is complicated by difficulties in ascertainment of families due to the late age of onset of the condition and the unreliability of a family history in a condition which is commonly sub-clinical. Family studies performed before the realisation of the distinction between Type 1 and Type 2 diabetes are very difficult to interpret $[34,35]$. The important role of other factors such as obesity and physical inactivity in making a sub-clinical defect clinically apparent means that a diabetic trait may not be apparent in a thin, fit person.

The studies of Köbberling and colleagues [36] attempted to overcome these problems by applying a statistical method developed by Stromgren [37] which included an age-correction of the probability of detecting diabetes in each first-degree relative of a diabetic proband, by taking into consideration the fraction of the lifetime risk of diabetes that had already passed. The latter was calculated from the age-specific prevalence rates in the population concerned, and the actual prevalence of diabetes in siblings, children and parents was adjusted to the predicted eventual prevalence if all members of the family reached 80 years of age. Using these methods Köbberling et al. predicted that between 43 and $45 \%$ of siblings, parents and children of Type 2 diabetic patients would eventually have diabetes if they live to 80 years of age, a percentage obviously suggestive of autosomal dominant inheritance [38].
Similarly O'Rahilly et al., without applying the Stromgren method but using a sensitive continuous infusion of glucose test with an age-correction for the criterion of glucose intolerance, found that $31 \%$ of siblings (mean age $54 \pm 12$ years) of diabetic patients who presented at over the age of 40 years were either diabetic or glucose intolerant [39]. Whilst this would be in accord with the data of Köbberling implying an autosomal dominant inheritance, the data of O'Rahilly et al. also suggested a "gene dose effect" which is important in relation to defining suitable families for linkage analysis. Patients who presented with diabetes before the age of 40 (early-onset diabetes, EOD) were found frequently to have both parents affected with diabetes or glucose intolerance. Thus, the early presentation of Type 2 diabetes may represent a homozygous presentation of a diabetogenic gene or genes. This hypothesis was supported by $69 \%$ of the siblings of EOD patients being either diabetic or glucose intolerant, which is not significantly different from the $75 \%$ expected by Mendelian inheritance from 2 heterozygote parents.

IF EOD is due in part to "double-gene dose" it is surprising that studies of the offspring of conjugal diabetic parents have not revealed a high incidence of early-onset diabetes [40-42], although this is suggested in a study by Viswanathen [43]. Most studies of the offspring of conjugal diabetic parents were carried out before Type 1 and Type 2 diabetes were separated, which may explain some of the discrepancies.

Further studies are needed to clarify any possible heterogeneity and it is possible that diabetes can arise from interaction of several genes affecting B-cell function and insulin action. Nevertheless, it seems likely that a common form of Type 2 diabetes is inherited as an autosomal dominant with a penetrance dependent on both age and obesity, a view supported by a recent WHO expert committee on diabetes [44].

\section{Ascertainment of Type 2 diabetic pedigrees for linkage studies}

For linkage analysis in a disease like Type 2 diabetes where there is a potential for genetic heterogeneity, it is probably better to study a limited number of large pedigrees rather than many small nuclear families. Three generation pedigrees are preferable as these provide extra information about the relationship between the disease and the marker. The problems associated with the ascertainment of large families suitable for linkage analysis in diabetes can be summarised as follows:

\section{Age of onset of disease}

The late age of onset of a majority of cases of non-insulin-dependent diabetes means that in most families one or both parents of the proband are dead. On the other hand, the affected children of middle-aged par- 


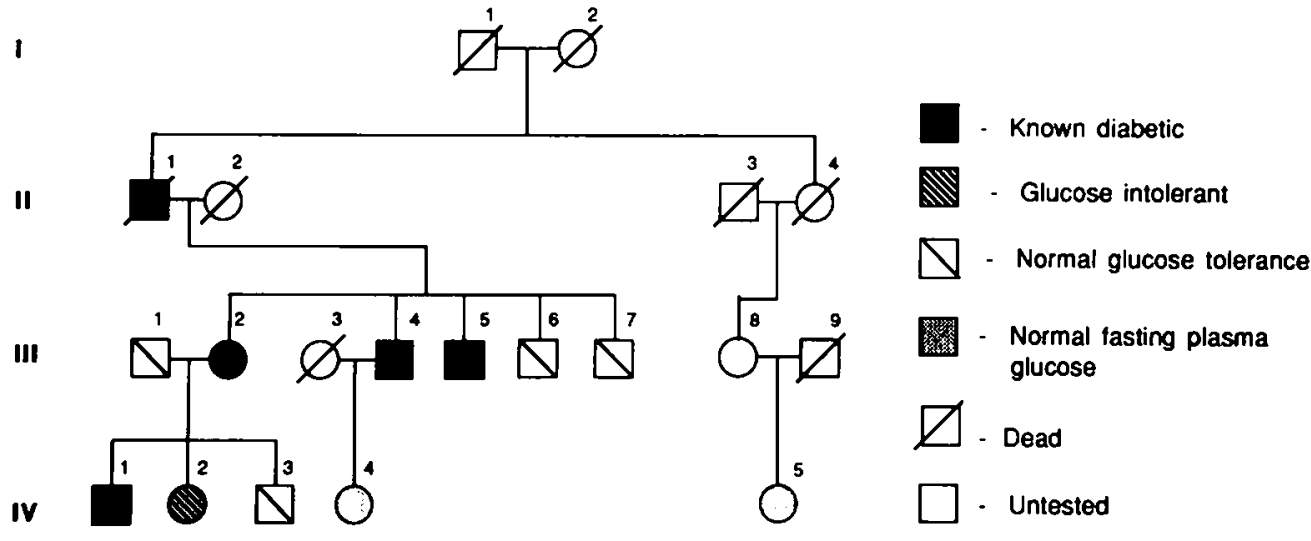

Fig. 1. Family BF appears to be ideal for linkage analysis with apparent autosomal dominant transmission through three generations. Inspection of hospital records, however, revealed that subject II 2 developed Type 2 diabetes late in life. The affected subjects in generation III could therefore have inherited diabctogenic genes from either parent, thus making linkage analysis more complex ents may not yet have expressed the disease. Thus the ascertainment of large two or three generation pedigrees is extremely difficult.

\section{Excess mortality}

This exacerbates the previous problem as it increases the likelihood that the crucial affected parent of a middle-aged diabetic proband will have succumbed to cardiovascular disease and therefore not be available for DNA analysis.

\section{High disease prevalence leading to genetically complex families}

On first reflection a high disease prevalence may not seem to be a problem as it eases the ascertainment of probands. There are three related aspects:

a) Diabetes in the untested, assumed-normal spouse. Type 2 diabetes has a prevalence of approximately $6-8 \%$ in the 7 th decade in most Caucasian populations $[1,45]$. It is therefore likely that some apparently normal spouses of affected family members might be contributing diabetogenic genes to the family. This could lead to a misinterpretation of results, and it is crucially important that all members of the family, including spouses, are tested for impaired glucose tolerance.

b) Families with more than one known diabetic individual. Pedigrees with a high prevalence of diabetes are likely to come to the attention of genetic investigators as a potentially valuable family for linkage analysis. If families with more than one known diabetic individual are chosen, this may introduce bias towards ascertaining families with more than one source of diabetic genes. A particular problem might arise if a family includes a diabetic individual presenting less than age 40 years (EOD), as then both parents are likely to be affected [39]. Similarly, if several siblings have diabetes it also probably increases the chance that both parents were affected. Figure 1 shows such a pedigree, which at first seemed suitable, until careful examination of hospital records revealed that both subject II1 and subject 112 had diabetes late in life. Obviously, one could seriously misinterpret the failure of two affected siblings in generation III to share a candidate haplotype, if one were not aware that both parents had diabetes. This type of complex pedigree makes linkage analysis very difficult.

c) Distinction between early-onset Type 2 Diabetes (EOD) and MODY. Patients presenting with diabetes in the 25-40 year old category are sometimes termed "MODY", in the absence of a family tree strongly suggestive of dominant inheritance [46]. Many of the pedigrees of Fajans et al. which were described as MODY families had two affected parents and the patients presenting at an early age may have been "double genedose" EOD's [46]. The term MODY should probably not be used to describe such families, and it should be restricted to families in which there is dominant inheritance of a disease presenting at age less than 25 years in the majority of family members [47]. Families with dominantly inherited MODY must be clearly distinguished from those with EOD for linkage analysis.

\section{Definition of normality and disease}

The diagnosis of diabetes still rests on an arbitrary cut off figure for plasma glucose both fasting and after a glucose load. The day to day variability of the oral glucose tolerance test is very large (coefficient of variation approximately $30 \%$ ) and this means that both false positive and false negative diagnoses are possible [48]. The WHO criteria for diabetes [49], i.e. fasting plasma glucose greater than $7.8 \mathrm{mmol} / \mathrm{I}$ with a $2 \mathrm{~h}$ post-prandial glucose of greater than $11.1 \mathrm{mmol} / \mathrm{l}$ may be appropriate for epidemiological studies; but may not be sufficiently sensitive to detect early glycaemic abnormalities in at-risk members of a family. In linkage analysis it is a less serious error to diagnose an affected individual as normal, as inclusion of age dependent penetrance factors allow the assumption that a certain number of individuals with a "diabetes gene" will remain unaffected until very late in life. Nevertheless, we pre- 
fer a less strict criterion for diabetes than WHO, and choose a fasting plasma glucose of greater than $6 \mathrm{mmol} / \mathrm{l}$. This is still more than 3 standard deviations above the normal range, and has been used as the criterion for entry into the UK Prospective Diabetes Study [50]. To define glucose intolerance, we have used the response to a continuous infusion of glucose of $5 \mathrm{mg} \cdot \mathrm{kg}$ ideal weight ${ }^{-1} \cdot \mathrm{min}^{-1}$ as this may have a lower coefficient of variation than an oral glucose tolerance test (unpublished observations). A $1 \mathrm{~h}$ glucose measurement above the mean $+2 \mathrm{SD}$ of a matched control group ( $9.3 \mathrm{mmol} / 1$ at age 40 years) has been considered abnormal even in subjects with a fasting plasma glucose $<6 \mathrm{mmol} / \mathrm{l}$ [51]. For linkage analysis a higher figure of +2.5 or $+3 \mathrm{SD}$ (i.e. more than 9.7 or $10 \mathrm{mmol} / \mathrm{l}$, respectively, at age 40 years) may be preferable.

Cerasi, Luft et al. considered a low insulin response to glucose as being a genetically determined marker of diabetes [52]. However the amplitude of the insulin response is crucially related to insulin sensitivity, with thin people and/or athletes having low insulin responses and obese, inactive people having high insulin responses [53]. Until it is feasible to define the expected insulin response for a subject more precisely, the diagnosis of diabetes will continue to be primarily on glucose rather than insulin levels.

\section{Family motivation}

A crucial feature of any linkage analysis project is to obtain the co-operation of all family members. Type 2 diabetes is often undiagnosed, relatively mild symptomatically and is often not perceived as life threatening, resulting in low motivation of unaffected family members. This difficulty in obtaining family co-operation contrasts markedly with diseases like Duchenne muscular dystrophy and cystic fibrosis, where devastating consequences in young children often lead to enthusiastic assistance with studies.

\section{Choice of genetic markers for study}

\section{Candidate genes}

Probes for genes, the malfunction of which might conceivably lead to diabetes, are increasingly becoming available to the investigator. In several MODY [27, 54] and one Type 2 diabetic pedigree [55] there was no evidence of linkage between the insulin gene itself and diabetes. Other candidates such as the insulin receptor gene [56], glucose transporter gene [57] and genes for various neuropeptides within the endocrine pancreas are all under investigation. It is important to be aware of the potential for heterogeneity. For instance, certain very rare forms of diabetes due to insulin gene mutations [58] will show close linkage to the insulin gene lo- cus, and these may not be detected among a large number of negative families.

\section{Random polymorphic markers}

The usefulness of a genetic marker is determined by the extent of its polymorphism. Highly variable region probes (HVRs) recognise specific stretches of non-coding DNA, the length of which vary due to a differing number of repeats of a basic core sequence. The polymorphism detected by HVRs is considerably greater than that found with probes which detect conventional RFLPs. Their potential in linkage analysis is exemplified by the success of the $3^{\prime}$ alpha globin HVR in localising adult polycystic kidney disease to the short arm of chromosome 16 [11]. Seventy-seven such HVR's have recently been generated by Nakamura and colleagues [59]. The widespread availability of such probes of known genetic localisation will greatly aid investigators in linkage analysis.

\section{DNA finger printing}

The "hypervariable minisatellite" probes first descibed by Jeffries et al. detect HVR's occuring throughout the genome [60]. The enormous variability of allele size at each locus combined with the large number of loci means each person has a characteristic "finger print" of DNA fragments. When DNA finger printing was described in 1985 it was considered that this technique would prove extremely valuable for linkage analysis [60]. Although the ability to examine up to 20 different genetic loci in one experiment is unique, it should be noted that DNA fingerprinting suffers from some serious limitations for disease linkage studies. Firstly it is not possible to discern which bands are allelic, and secondly, the chromosomal localisation of the bands is unknown. Nevertheless, if in a large pedigree a single band strongly segregates with a disease, this would make it worthwhile to clone the individual band to determine its genetic localisation. A preliminary report from Kastern et al. has recently reported some success using DNA fingerprinting in rodent diabetes [61].

\section{Possible strategies for Type 2 diabetes}

It is apparent from the discussion above that the main problem faced by investigators concerned with the localisation of the genetic defect or defects underlying Type 2 diabetes is the ascertainment of families which are large enough to prove or disprove linkage. The following strategies are likely to be helpful:

\section{Ascertain pedigrees through an elderly Type 2 diabetic proband who has a living non-diabetic spouse}

One could have a reasonable degree of certainty that testing their offspring, who would be aged approxi- 
mately 50 or 60 years, would allow fairly reliable categorisation into normal or glucose intolerant/diabetic subjects.

Find a particular sub-type of the disease which has an earlier age of onset and which may provide clues regarding the genetics of the more common disease

This has been used with success in Alzheimer's disease [16]. MODY is an example which has been investigated, but other sub-types of diabetes, e.g. specific insulin resistant states, should become available. It is possible that the genetic basis for MODY will be different from that of "common" Type 2 diabetes, although clinical heterogeneity can result from different molecular defects of the same gene as illlustrated by the different beta-haemoglobinopathies [62].

\section{A strategy which overcomes the difficulties of family ascertainment is the use of several affected sibling-pairs [63]}

The sharing of a specific allele more than would be expected by chance may suggest linkage, but this will then need to be tested in families. Although this method overcomes some of the problems of population association studies (in particular the problem of matching for ethnic background) the method is critically dependent for statistical power on highly polymorphic probes and is particularly susceptible to obfuscation by any genetic heterogeneity.

Most previous pedigree studies in diabetes have used simple linkage analysis assuming complete penetrance of the trait in all family members studied, irrespective of age. This is obviously not appropriate in a disease with a late age of onset. Modern linkage analysis computer packages such as LINKAGE enable age-dependent penetrance to be taken into account [64]. This can either be taken from the age-specific prevalence data for the population as a whole or, if the family is large, it can be calculated from the age of onset distribution in the family. The latter is useful for MODY families where population data is lacking. As the number of available DNA probes increases, interval mapping [65], a statistical technique which analyses linkage information from more than one probe simultaneously, will be useful. This allows more statistical certainty of linkage or non-linkage for any given number of informative matings and may be particularly applicable to disorders like diabetes where it may be difficult to find large multi-generation pedigrees.

\section{Conclusions}

From the lead given by the successes in other diseases, it is apparent that linkage analysis of genetic markers in large well-defined families is likely to be the most fruitful approach to the search for genetic markers in Type 2 diabetes. The recent finding of a specific peptide forming the amyloid found in the diabetic islet may provide another candidate gene to test in this fashion [66]. The study of candidate genes such as this, and continuing study of random highly polymorphic markers should eventually enable diabetes susceptibility genes to be identified.

Acknowledgements. SOR was the Redcliffe-Maud Fellow of the British Diabetic Association. We thank Ms. P. Patel for expert technical assistance, and Ms. P. Farmer for preparation of the manuscript.

\section{References}

1. Zimmet $P$ (1982) Type 2 (non-insulin-dependent) diabetes - an epidemiological overview. Diabetologia 22: 399-411

2. Neel JV (1965) Diabetes mellitus. In: Neel JV, Shaw MW, Schull WJ (eds) The genetics and epidemiology of chronic disease. US Public Health Service publications, Washington, pp 105-132

3. Bottazzo GF, Florin Christensen A, Doniach D (1974) Islet cell antibodies in diabetes mellitus with auto-immune polyendocrine deficiencies. Lancet II: 1279-1282

4. Cudworth AG, Woodrow JC (1972) HLA antigens and diabetes mellitus. Lancet II: 1153

5. Todd JA, Bell JI, McDevitt HO (1987) HLA-DQbeta gene contributes to susceptibility and resistance to insulin-dependent diabetes mellitus. Nature 329: 599-604

6. Comings DE (1980) Prenatal diagnosis and the new genetics. Am J Hum Genet 32: 453

7. Cooper DN, Schmidtke J (1984) DNA restriction fragment length polymorphisms and heterozygosity in the human genome. Hum Gen 66: 1-16

8. Donis-Keller H, Green P, Helms C, Cartinhour S, Weiffenbach B, Stephens K, Keith TP, Bowden DW, Smith DR, Lander ES, Botstein D, Akots G, Rediker KS, Gravius T, Brown VA, Rising MB, Parker C, Powers JA, Watt DE, Kauffman ER, Bricker A, Phipps P, Muller-Kahle H, Fulton TR, Ng S, Schumm JW, Braman JC, Knowlton RG, Barker DF, Crooks SM, Lincoln SE, Daly MJ, Abrahamson J (1987) A genetic linkage map of the human genome. Cell 51: 319-337

9. Knowlton RG, Cohen-Haguenauer O, Van Cong N, Frezal J, Brown VA, Barker D, Braman JC, Schumm JW, Tsui LC, Buchwald M, Donis-Keller H (1985) A polymorphic CNA marker linked to cystic fibrosis is located on chromosome 7. Nature 318 : 381-382

10. Monaco AP, Neve RL, Colletti-Feener C, Bertelson CJ, Kurnit DM, Kunkel LM (1986) Isolation of candidate cDNAs for portions of the Duchenne muscular dystrophy gene. Nature 323: $646-650$

11. Reeders ST, Breuning MH, Davies KE, Nicholls RD, Jarman AP, Weatherall DJ (1985) A highly polymorphic DNA marker linked to adult polycystic kidney disease on chromosome 16. Nature 317: $542-544$

12. Simpson NE, Kidd KK, Goodfellow PJ, McDermid H, Myers S, Kidd JR, Jackson CE, Duncan AMV, Farrer LA, Brasch K, Castiglione $C$, Genel M, Gertner J, Greenberg CR, Gusella JF, Holden JJA, White BN (1987) Assignment of multiple endocrine neoplasia type $2 \mathrm{~A}$ to chromosome 10 by linkage analysis. Nature 328: $528-530$

13. Bodmer WF, Bailey CJ, Bodmer J, Bussey HJR, Ellis A, Gorman P, Lucibello FC, Murday VA, Rider SH, Scambler P, Sheer D, Solomon E, Spurr NK (1987) Localization of the gene for familial adenomatous polyposis in chromosome 5. Nature 328: 614-616 
14. Barker D, Wright E, Nguyen K, Cannon L, Fain P, Goldgar D, Bishop DT, Carey J, Baty B, Kivlin J, Willard H, Waye JS, Greig G, Leinwand L, Nakamura Y, O'Connell P, Leppert M, Lalouel JM, White R, Skolnick M (1987) Gene for von Recklinghausen neurofibromatosis is in the pericentromeric region of chromosome 17. Science 236: 1100-1102

15. Egeland JA, Gerhard DS, Pauls DL, Sussex JN, Kidd KK (1987) Bipolar affective disorders linked to DNA markers on chromosome II. Nature 325: 783 787

16. St George-Hyslop PH, Tanzi RE, Polinsky RJ, Haines JL, Nee L, Watkins PC, Myers RH, Fcldman RG, Pollen D, Drachman D, Growdon J, Bruni A, Foncin JF, Salmon D, Frommelt P, Amaducci L, Sorbi S, Piacentini S, Stewart GD, Hobbs WJ, Conneally PM, Gusella JF (1987) The genetic defect causing familial Alzheimer's disease maps on chromosome 21. Science 235: 885-890

17. Briggs BR, Jackson WPU, DuToit ED, Botha MC (1980) The histocompatibility (HLA) antigen distribution in diabetes in Southern African Blacks (Xhosa). Diabetes 29: 68-70

18. Williams RC, Knowler WC, Butler WJ, Pettit DJ, Lisse JR, Bennett PH, Mann DL, Johnson AH, Terasaki PI (1981) HLA-A2 and Type 1 (insulin-independent) diabetes mellitus in Pima Indians: an association of allele frequency with age. Diabetologia 21: $460-463$

19. Groop L, Koskimies S, Pelkonen R, Tolppanen F-M (1983) Increased frequency of HLA-Cw4 in type 2 diabetes. Acta Endocrinol 104: 475-478

20. Stern MP, Ferrell RE, Rosenthal M, Haffner SM, Hazuda HP (1986) Association between NIDDM, RH blood group, and haptoglobin phenotype. Diabetes $35: 367 \ldots 391$

21. Rotwein PS, Chirgwin J, Province M, Knowler WC, Pettitt DJ, Permutt MA (1983) Polymorphism in the $5^{\prime}$-flanking region of the human insulin gene: a genetic marker for non-insulin-dependent diabetes. $N$ Engl J Med 308: 65-71

22. Owerbach D, Nerup J (1982) Restriction fragment length polymorphism of the insulin gene in diabetes mellitus. Diabetes 31: 275.277

23. Emery AEH (1986) Methodology in medical genetics, 2nd edn. Churchill Livingstone, Edinburgh

24. Lander ES, Botstein D (1986) Mapping complex genetic traits in humans: new methods using a complete RFLP linkage map. Cold Spring Harbor Symp Quant Biol 51: 49-62

25. Ott $\mathbf{J}$ (1985) Analysis of human genetic linkage, 1st edn. John Hopkins University Press, Baltimore

26. Tattersall RB, Fajans S (1975) A difference between the inheritance of classical juvenile-onset and maturity-onset type diabetes of young people. Diabetes 24: 44. 53

27. Galton DJ, Hitman GA (1985) DNA polymorphisms and the insulin gene: disease associations. Diabetic Medicine 2: 159-162

28. Elbein SC, Borecki I, Corsetti L, Fajans SS, Hansen AT, Nerup J, Province M, Permutt MA (1987) Linkage analysis of the human insulin receptor gene and maturity onset diabetes of the young. Diabetologia 30: 641-647

29. Serjeantson SW, Zimmet P (1982) Analysis of linkage relationships in maturity-onset diabetes of young people and independent segregation of $\mathrm{C} 6$ and HLA. Hum Genet 62: 214-216

30. Barnett AH, Eff C, Leslic RDG, Pyke DA (1981) Diabetes in identical twins: a study of 200 pairs. Diabetologia 20:87-93

31. Rushforth NB, Bennett PH, Sternberg AG, Burch TA, Miller M (1971) Diabetes in the Pima indians, evidence of bimodality in glucose tolerance distributions. Diabetes $20: 756-765$

32. Zimmet P, Whitehouse S (1978) Bimodality of fasting and twohour glucose tolerance distributions in a Micronesian population. Diabetes 27: 793800

33. Raper LR, Taylor R, Zimmet P, Milne B, Balkau B (1984) Bimodality in glucose tolerance distributions in the urban Polynesian population of Western Samoa. Diabetes Res 1:19-26

34. Steinberg AG (1961) Heredity in diabetes mellitus. Diabetes 10 : 269...274

35. Falconer DS, Duncan LJP, Smith C (1971) A statistical and genetic study of diabetes. Ann Hum Genet 34: 347.367

36. Kobberling J, Tillil H (1982) Emperical risk figures for first de- gree relatives of non-insulin dependent diabetics. In: Kobberling $\mathrm{J}$, Tattersall R (eds) The genetics of diabetes meilitus. Academic Press, London, p 201-209

37. Stromgren (1935) Zum Ersatz des Weinbergschen abgekürzten Verfahrens. Zugleich ein Beitrag zur Frage von der Erblichkeit des Erkrankungsalters bei der Schizophrenie. Z Gesamte Neurol Psychiatr 153: 784-797

38. Kobberling J, Tillil H, Lorenz HJ (1985) Genetics of Type 2Aand Type 2B-Diabetes Mellitus. Diabetes Res Clin Pract 1: 311 (Abstract)

39. O'Rahilly S, Spivey RS, Holman RR, Nugent Z, Clark A, Turner RC (1987) Type II diabetes of early onset: a distinct clinical and genetic syndrome? Br Med J 294: 923-928

40. Tattersall R, Fajans SS (1975) Diabetes and carbohydrate tolerance in 199 offspring of 37 conjugal diabetic parents. Diabetes 24: $452-462$

41. Kahn CB, Soeldner JS, Gleason RE, Rojas L, Camerini-Davalos RA, Marble $A$ (1969) Clinical and chemical diabetes in the offspring of diabetic couples. N Engl J Med 281: 343-346

42. Cooke AM, Fitzgerald MG, Malins JM, Pyke DA (1966) Br Med J 2: 674-676

43. Viswanathan $M$, Mohan V, Snehelatha C, Ramachandran A (1985) High prevalence of Type 2 (non-insulin-dependent) diabetes among the offspring of conjugal Type 2 diabetic parents in India. Diabetologia 28: $907-910$

44. WHO technical report series (1985) No 727, Geneva

45. Ohlson L-O, Larsson B, Eriksson H, Svardsudd K, Welin L, Tibblin G (1987) Diabetes mellitus in Swedish middlc-aged men. The study of men born in 1913 and 1923. Diabetologia 30: 386-393

46. Fajans SS (1982) Heterogeneity between various families with non-insulin-dependent diabetes of the MODY type. In: Kobberling J, Tattersall $\mathrm{R}$ (eds) The genetics of diabetes mellitus. Academic Press, London, p 251 260)

47. O'Rahilly S, Tumer RC (1988) Early onset Type II diabetes v MODY: evidence for the existence of two discrete diabetic syndromes. Diabetic Medicine 5: 224-234

48. McDonald GW, Fisher GF, Burnham C (1965) Reproducibility of the oral glucose tolerance test. Diabetes 14: 473-480

49. WHO technical report series (1980) No 646, Geneva

50. Multicentre Study (1983) UK prospective study of therapies of maturity-onset diabetes. Diabetologia 24: 404-411

51. O'Rahilly SP, Nugent Z, Rudenski AS, Hosker JP, Bumett MA, Darling P, Turner RC (1986) Beta-cell dysfunction, rather than insulin insensitivity is the primary defect in familial type 2 diabetes. Lancet I: 360-363

52. Cerasi E, Luft R, Ffendic S (1972) Decreased sensitivity of the pancreatic beta cells to glucose in prediabetic and diabetic subjects. Diabetes 21: 224-234

53. Wirth A, Diehm C, Mayer H (1987) Plasma C-peptide and insulin in trained and untrained subjects. J Appl Physiol 50 (1): 71-77

54. Andreone T, Fajans S, Rotwein P, Skolnick M, Permutt A (1985) Insulin gene analysis in a family with maturity onset diabetes of the young. Diabetes 34: 108-112

55. Hitman GA, Jowett NI, Williams LG, Humphries S, Winter RM, Galton DJ (1984) Polymorphisms in the 5'-flanking region of the insulin gene and non-insulin-dependent diabetes. Clin Sci 66: 383-388

56. Ullrich A, Bell JR, Chen EY, Herrara R, Petruzzelli LM, Dull TJ, Gray A, Coussens L, Liao YC, Tsubokawa M, Mason A, Seeburg PH, Grunfeld C, Rosen OM, Ramachandran J (1985) Human insulin receptor and its relationship to the tyrosine kinase family of oncogenes. Nature 313: 756-761

57. Shows TB, Eddy RL, Byers MG, Fukushima Y, Dehaven CR, Murray JC, Bell GI (1987) Polymorphic Human Glucose Transporter Gene (GLUT) is on Chromosome 1p31.3-p35. Diabetes 36: $546-549$

58. Tager HS (1984) Abnormal products of the human insulin gene. Diabetes 33: 693-699

59. Nakamura Y, Leppert M, O'Connell P, Wolff R, Holm T, Culver 
M, Martin C, Fujimoto E, Hoff M, Kumlin E, White R (1987) Variable number of tandem repeat (VNTR) markers for human gene mapping. Science 235: 1616-1622

60. Jeffreys AJ, Wilson V, Thein SL (1985) Hypervariable 'minisatellite' regions in human DNA. Nature 314: 67-73

61. Kastern W, Kryspin-Sorensen I (1987) A repetitive DNA sequence used to detect linkage of polymorphic DNA fragments with diabetes in the BB rat. Diabetologia 30:537 (Abstract)

62. Orkin SH, Kazazian HZH, Antonarakis SE, Goff SC, Boehm CD, Sexton JP, Naber PG, Giardina PJV (1982) Linkage of Beta Thalassemia mutations and beta globin gene polymorphisms with DNA polymorphisms in the human beta globin cluster. $\mathrm{Na}$ ture 296: 627-631

63. Suarez BK (1983) A Sib-Pair Strategy for the Use of Restriction Fragment Length Polymorphisms to Study the Mode of Transmission of Type II Diabetes. Am J Hum Genet 35: 34-48

64. Lathrop GM, Lalouel JM, Julier C, Ott J (1984) Strategies for multilocus linkage analysis in humans. Proc Natl Acad Sci USA 81: 3443-3446
65. Lander ES, Botstein D (1986) Strategies for studying heterogeneous genetic trait in humans by using a linkage map of restriction fragment length polymorphisms. Proc Natl Acad Sci 83: $7353-7357$

66. Cooper GJS, Willis AC, Clark A, Turner RC, Sim RB, Reid KBM (1987) Purification and characterization of a peptide from amyloid-rich pancreases of type 2 diabetic patients. Proc Natl Acad Sci 84: 8628-8632

Received: 2 March 1988

Dr. Stephen O'Rahilly

Diabetes Research Laboratories

Radcliffe Infirmary

Woodstock Road

Oxford OX2 6HE

UK 